\begin{tabular}{|l|l|l||}
\hline \multicolumn{2}{|c|}{ PublisherInfo } \\
\hline \hline PublisherName & $:$ & BioMed Central \\
\hline \hline PublisherLocation & $:$ & London \\
\hline \hline PublisherImprintName & $:$ & BioMed Central \\
\hline \hline
\end{tabular}

\title{
Articles selected from Faculty of 1000 in November 2003
}

\begin{tabular}{|l|l|l||}
\hline \multicolumn{2}{|c|}{ ArticleInfo } \\
\hline \hline ArticleID & $:$ & 745 \\
\hline \hline ArticleDOI & $:$ & $10.1186 /$ bcr743 \\
\hline \hline ArticleCitationID & $:$ & E5 \\
\hline \hline ArticleSequenceNumber & $:$ & 17 \\
\hline \hline ArticleCategory & $:$ & Article selection \\
\hline \hline ArticleFirstPage & $:$ & 1 \\
\hline \hline ArticleLastPage & $:$ & 2 \\
\hline \hline & & RegistrationDate : 2003-11-5 \\
\hline ArticleHistory & $:$ & OnlineDate \\
\hline \hline ArticleCopyright & $:$ & The Author(s)2003-11-5 \\
\hline \hline ArticleGrants & $:$ & \\
\hline \hline ArticleContext & $:$ & 130586611 \\
\hline \hline
\end{tabular}


Valerie Speirs, Aff1

Corresponding Affiliation: Aff1

Email: v.speirs@leeds.ac.uk

Aff1 Molecular Medicine Unit, University of Leeds, St James's University

Hospital, Leeds LS9 7TF, UK

\section{Articles selected from Faculty of 1000}

\section{References}

1. Thornton JW, Need E, Crews D: Resurrecting the ancestral steroid receptor: ancient origin of estrogen signaling. Science. 2003, 301: 1714-1717. For the Faculty of 1000 evaluation of this article please see http://breast-cancer-research.com/reports/bcr743.asp\#thornton

2. Lindberg MK, Movérare S, Skrtic S, Gao H, Dahlman-Wright K, Gustafsson JA, Ohlsson C: Estrogen receptor (ER)-beta reduces ERalpha-regulated gene transcription, supporting a "ying yang" relationship between ERalpha and ERbeta in mice. Mol Endocrinol. 2003, 17: 203-208. For the Faculty of 1000 evaluation of this article please see http://breast-cancer-research.com/reports/ bcr743.asp\#lindberg

3. Narita M, Nunez S, Heard E, Narita M, Lin AW, Hearn SA, Spector DL, Hannon GJ, Lowe SW: Rbmediated heterochromatin formation and silencing of E2F target genes during cellular senescence. Cell. 2003, 113: 703-716. For the Faculty of 1000 evaluation of this article please see http://breast-cancerresearch.com/reports/bcr743.asp\#narita

4. Shi Y, Evans JE, Rock KL: Molecular identification of a danger signal that alerts the immune system to dying cells. Nature. 2003, 425: 516-521. For the Faculty of 1000 evaluation of this article please see http://breast-cancer-research.com/reports/bcr743.asp\#shi

5. McMurray MA, Gottschling DE: An age-induced switch to a hyper-recombinational state. Science. 2003, 301: 1908-1911. For the Faculty of 1000 evaluation of this article please see http://breast-cancerresearch.com/reports/bcr743.asp\#mcmurray

This PDF file was created after publication. 